\title{
The European Journal of Ageing and the importance of science
}

\author{
Marja Aartsen $^{1} \cdot$ Matthias Kliegel $^{2} \cdot$ Morten Wahrendorf $^{3}$
}

Published online: 11 February 2022

(c) The Author(s), under exclusive licence to Springer Nature B.V. 2022

The editorial of 2021 qualified the year 2020 as a "horrible year" due to the COVID-19 pandemic and raised the question what it would bring to the future of ageing research (Iwarsson et al. 2021). One year later, and 2 years after the start of the pandemic, we are again living under strict regulations of social distancing, wearing facemasks, and taking COVID-19 vaccine booster-shots to slow down the spread of the even more infectious mutant of the virus and protect hospitals from being pushed over the edge of their capacities. The response of the academic world with studies on COVID19 was impressive. Many good studies on the virus and the consequences of the pandemic were conducted, of which the European Journal of Ageing published a fraction in the special section on the social, behavioral, and public health consequences of COVID-19. One of the main conclusions the guest editors draw was that the pandemic deeply affected the social contacts of older people as many were cut-off from their loved ones or the wider society. Particularly frail older people were hard hit by social distancing imposed by nursing homes or by their own fear of getting infected (Tesch-Römer and Lamura 2021).

With the pandemic ongoing, scientists addressed new and pressing questions such as whether the impact of the pandemic on the mental health of older people has changed over time (Hansen et al. 2021) or how images of older people changed from "vulnerable old" to "fellow citizens of higher age" (Ellerich-Groppe et al. 2021). A second special section on the COVID-19 pandemic is in the pipeline and will appear in print in the European Journal of Ageing this year. It is entirely based on data from SHARE (Survey of Health, Ageing and Retirement in Europe) and the Corona survey-a special survey that asked SHARE respondents

Marja Aartsen

maraar@oslomet.no

1 NOVA Norwegian Social Research, Oslo Metropolitan University, Oslo, Norway

2 Université de Genève, Genève, Switzerland

3 Universitätsklinikum Düsseldorf, Düsseldorf, Germany about their experiences during the pandemic (Börsch-Supan 2020). This special section will include, among others, studies on the economic stress (Chłon-Domińcza and HolzerŻelażewska 2021) and economic vulnerability of older Europeans (Arnault et al. 2021).

Yet, other journals published studies touching upon the concerning and growing impact of information and communication technology on our behavior, beliefs, and opinions. For example, a study about how the COVID-19 vaccination pass has increased inequalities among citizens (Tazzioli 2021); how adherence to COVID-regulations became politicized (Stroebe et al. 2021); and that social media and artificial intelligence (AI) contribute to the polarization of opinions about what is good or not in our fight against the pandemic (Jiang et al. 2021).

How AI influences our behavior and opinions, becomes clear in a recent Netflix documentary "The Social Dilemma" where a grim picture is sketched by leading figures of Google, Instagram, and Facebook (Orlowski 2020). The documentary shows how the Internet, based on capitalistic motives, tries to capture our time and attention in the hope that we buy the products that we do not need, or influence behavior and opinions without us being aware of it. It also shows how opinions and voting behavior during the recent presidential elections in the United States became polarized and even violent, by not sharing the complete factual information. The founders argue that it is no longer a single human being or organization that can be blamed for the potential threat or misleading information, but the AI itself acting as an automaton. The documentary is a must-see for all of us, even for those who are keen on not leaving traces of activity or accepting cookies. It shows that scientific knowledge is more than ever crucial to understand the increasingly complex world in which we live and to combat theories without any empirical ground.

Now on a brighter note. We are grateful to the increasing number of submissions and to all scientists that send their manuscripts to our journal. It was with great pleasure that we learned that the impact factor of our journal further increased to 2.711, ranking now at the 16th position of the 
36 academic journals in Gerontology. On behalf of the whole editorial team, we would like to extend our sincere thanks to all authors who submitted their work to the journal and to editorial board members and fellow scientists who reviewed these studies. We also would like to express our gratitude to the various guest editors that helped compiling special sections on important and highly relevant topics for the journal such as the special section on "New thinking about health expectancy" (edited by Aïda Solé-Auró and Dorly Deeg 2021) and the special section on "Older migrants and loneliness" (edited by Tineke Fokkema and Ruxandra Oana Ciobanu 2021). More special sections are foreseen in the year to come, among which as mentioned another special section about COVID-19, and a special section about social inequalities in ageing. To handle the increasing number of submissions, we have now recruited two highly qualified associate editors, Thorsten Kneip of the Max Planck Institute für Sozialrecht und Sozialpolitik, and Héctor Pifarré i Arolas of the Center for Research in Health and Economics in Barcelona who will oversee the share of submissions that fits to their field of knowledge.

Finally, we express our hopes that an open society is possible again soon and call for inspiring and ground-breaking scientific research as we should not forget the importance of providing objective knowledge to fight against polarization and politization, to help reducing inequalities in health and wellbeing, and promote factual information that helps designing effective health campaigns and interventions.

\section{References}

Arnault L, Jusot F, Renaud T (2021) Economic vulnerability and unmet healthcare needs among the population aged $50+$ years during the COVID-19 pandemic in Europe. Eur J Ageing. https://doi.org/10. 1007/s10433-021-00645-3

Börsch-Supan A (2020) Survey of health, ageing and retirement in Europe (SHARE) Wave 8. COVID-19 Survey 1. Release version: 1.0.0. SHARE-ERIC. Data set
Chłoń-Domińczak A, Holzer-Żelażewska D (2021) Economic stress of people $50+$ in European countries in the Covid-19 pandemic-do country policies matter? Eur J Ageing. https://doi.org/10.1007/ s10433-021-00662-2

Ellerich-Groppe N, Pfaller L, Schweda M (2021) Young for old-old for young? Ethical perspectives on intergenerational solidarity and responsibility in public discourses on COVID-19. Eur J Ageing 18:157-191. https://doi.org/10.1007/s10433-021-00623-9

Fokkema T, Ciobanu RO (2021) Older migrants and loneliness: scanning the field and looking forward. Eur J Ageing 18:291-297. https://doi.org/10.1007/s10433-021-00646-2

Hansen T, Sevenius Nilsen T, Knapstad M et al (2021) Covid-fatigued? A longitudinal study of Norwegian older adults' psychosocial well-being before and during early and later stages of the COVID-19 pandemic. Eur J Ageing. https://doi.org/10.1007/ s10433-021-00648-0

Iwarsson S, Aartsen MJ, Wahrendorf M, Kliegel M (2021) What will the horrible year of 2020 bring to the future of ageing research? Eur J Ageing 18:1-3. https://doi.org/10.1007/ s10433-021-00606-w

Jiang J, Ren X, Ferrara E (2021) Social media polarization and echo chambers: a case study of COVID-19. arXiv preprint arXiv:2103. 10979

Orlowski J (Director) (2020) The social dilemma [Documentary; online videa]. Netflix Originals

Solé-Auró A, Deeg DJH (2021) New thinking about health expectancy: introduction to the special section. Eur J Ageing 18:439-441. https://doi.org/10.1007/s10433-021-00630-w

Stroebe W, van Dellen MR, Abakoumkin G, Lemay EP Jr, Schiavone WM, Agostini M et al (2021) Politicization of COVID-19 healthprotective behaviors in the United States: Longitudinal and crossnational evidence. PLoS ONE 16(10):e0256740

Tazzioli M (2021) A "Passport to Freedom"? COVID-19 and the Rebordering of the World. Eur J Risk Regul 12(2):355-361. https:// doi.org/10.1017/err.2021.31

Tesch-Römer C, Lamura G (2021) Older adults in the first wave of the Corona pandemic. Eur J Ageing 18:145-147. https://doi.org/10. 1007/s10433-021-00629-3a

Publisher's Note Springer Nature remains neutral with regard to jurisdictional claims in published maps and institutional affiliations. 